\title{
Outcome Measures in Solid Organ Donor Management Research - a Systematic Review
}

\section{Kasia D Bera ( $\sim$ bera@doctors.org.uk)}

University of Oxford https://orcid.org/0000-0003-3795-6762

Akshay Shah

Oxford University: University of Oxford

MR English

Oxford University: University of Oxford

\section{RJ Ploeg}

University of Oxford Nuffield Department of Surgical Sciences

\section{Research}

Keywords: Organ Donation, Transplantation, Outcome measures, Organ donor management, systematic review, clinical trials, core outcome set

Posted Date: March 18th, 2021

DOI: https://doi.org/10.21203/rs.3.rs-321188/v1

License: (c) (i) This work is licensed under a Creative Commons Attribution 4.0 International License. Read Full License 


\section{Abstract}

\section{Background}

To systematically review published outcome measures across randomised controlled trials (RCTs) of donor management interventions.

\section{Methods}

The systematic review was conducted in accordance with recommendations by the Cochrane Handbook and PRISMA statement. We searched MEDLINE, EMBASE, CENTRAL, Web of Science as well as trial databases from 1980 to December 2019 for RCTs of donor management interventions.

\section{Results}

Twenty-two RCTs ( $\mathrm{n}=3432$ donors) were included in our analysis. Fourteen RCTs (63.6\%) reported a primary outcome relating to a single organ only. Eight RCTs primarily focused on aspects of donor optimisation in critical care. Thyroid hormones and methylprednisolone were the most commonly evaluated interventions (five and four studies, respectively). Only two studies, focusing on single organs (e.g. kidney), evaluated outcomes relating to other organs. The majority of studies evaluated physiological or biomarker-related outcomes. No study evaluated recipient health-related quality of life. Only one study sought consent from potential organ recipients.

\section{Conclusions}

The majority of RCTs evaluating donor management interventions only assessed single organ outcomes or effects on donor stability in critical care. There is a need for an evaluation of patient-centred recipient outcomes, and standardisation and reporting of outcome measures for future donor management RCTs.

\section{PROSPERO Registration}

CRD42018109487

\section{Background}

Solid organ transplantation is the preferred cost-effective treatment for end stage organ failure. However, the demand for organs for transplantation currently outweighs the available organ pool despite advances in organ preservation and recipient immunosuppression. Improved organ preservation strategies allow to bridge the time and distance between donor and recipient, and with more experience and better immunosuppression, we have seen a sharp decline in post-transplant morbidity and mortality. Nowadays, the remaining key problem in transplantation is the global persistent shortage of suitable deceased donor organs Due to the lack of available donor organs, mortality rates continue to remain high for those who remain on the transplant waiting list. The majority of deceased organs donated in the UK (60\%) and across Europe (over 85\%) are from donors with confirmed brain death (Donation after Brain Death, DBD), typically managed in intensive care units (ICUs) prior to organ procurement (1-3). The systemic sequelae of cerebral injury leading to brain death include hormonal, inflammatory and haemodynamic changes with significant cardiovascular instability and inevitably a degree of organ damage in the donor. As a result, organs from DBD donors are often declined due to a perceived or actual suboptimal quality. Conversely, the shortage of donor organs has led transplant centres to accept organs from older and higher risk donors often with pre-existing comorbidities enhancing the likelihood of injury prior to transplantation.

After confirmation of brain death and until retrieval of organs by an organ retrieval team, management in the ICU shifts towards donor optimisation. The cornerstones of donor optimisation include: correction of hypovolaemia, maintenance of organ perfusion, corticosteroid therapy, treatment of diabetes insipidus, and lung protective ventilation. The interventions 
used to delivery these goals have largely been extrapolated from general intensive care unit (ICU) patients or based on pathophysiological rationale $(4,5)$. In the UK, recommendations for optimisation of the brain dead donor have been summarised in a recommended 'donor management bundle' (6). With emerging techniques and targeted interventions identified in pre-clinical research, it is important to study whether these interventions do indeed translate into improved organ donor stability, quality of organs at the point of being offered to transplant centres and ultimately improved recipient graft function, survival and health-related quality of life. Furthermore, any systemic treatment administered to the donor can affect all organs and might have different short- or long-term effects on individual organs. In the UK, on average 3.6 organs are successfully transplanted from a brain dead donor (7), thus for any donor management intervention to be translated into clinical practice the effects on all organs must be known to be accepted by the entire transplant community.

Over the past two decades, many randomised control trials (RCTs) of donor interventions or treatments have been conducted to address these evidence gaps. However, in the absence of a core outcome set, there is likely to be widespread variation on the selection and timing of relevant donor and recipient outcome measures, assessment of alternative solid organs and consent processes. We therefore aimed to systematically assess and compare published outcome measures across RCTs of brain-dead donor management interventions.

\section{Methods}

\section{Protocol and registration}

The protocol for this systematic review was registered with PROSPERO (CRD42018109487) This review was conducted in agreement with the Preferred Reporting Items for Systematic Reviews and Meta-Analyses (PRISMA) reporting guidelines (8) (PRISMA Checklist, Additional File 1)

\section{Eligibility and study selection}

RCTs of intervention of adult deceased brain-dead donors were included. Studies involving treatments administered after organ procurement was initiated or applied to the retrieved organs alone were excluded. Preclinical and animal studies were also excluded. Studies published in more than one report, such as sub-studies, nested studies or follow up reports were combined. Investigators for studies with outstanding results or minimal information available were contacted, and studies only included if a response with further information was received. One French study was kindly translated by a native speaker to allow inclusion (9). No other studies published in other languages were identified.

\section{Search strategy and data extraction}

We searched MEDLINE, EMBASE, CENTRAL, Web of Science as well as trial databases (clinicaltrials.gov, WHO International Clinical Trials Registry Platform) from 1980 to July 2019 for RCTs of donor management interventions. An updated complete search was conducted on 28 Dec 2019 and a further focussed search of publications of the past year was undertaken in February 2021. A detailed search strategy is available in Additional file 2. Conference abstracts of major international conferences in the fields of transplantation and intensive or critical care were screened (include list and years). All languages were included. Conferences without available online abstracts were contacted. Two reviewers independently screened the titles and abstracts identified by the literature search. Any disagreement was resolved by consensus after discussion or by arbitration by a third author.

A data collection form was created and piloted on ten studies with three authors (KDB, MRE, AS) present, remaining data was extracted by three authors independently. Disagreement were resolved through discussion or by arbitration by a fourth author (RP). We extracted information regarding setting, donor and recipient characteristics, intervention types and outcomes. Two reviewers independently assessed the risk of bias of the included studies using the Collaboration tool for assessing risk of bias (10). Overall risk of bias for each study was then assigned low (all domains low); unclear (one or more domains unclear); high (one or more domains high). We assigned an 'unclear' rating when the study did not report a specific domain in 
the published paper or protocol. We did not contact study authors for verbal clarification. Microsoft Excel was used for data extraction and risk of bias assessment, RevMan was used to create the risk of bias plots (11).

\section{Data analysis}

For each study, all primary and secondary registered and reported outcome measures were recorded. Studies were grouped by type of systemic intervention (e.g. steroids) but also by primary target organ (e.g. studies clearly stating kidney graft survival or delayed graft function or creatinine as their primary outcome). For each group of studies using an identified intervention, all reported outcomes by donated organ or impact on donor stability were identified. For each group of studies with the same primary target organ, outcomes were identified and grouped into early (< 28 days after transplantation), late (> 28 days after transplantation) or biochemical-only outcome measures. Microsoft Excel was used for data collection and analysis. Abacus diagrams were created in Lucidchart (www.lucidchart.com). As the purpose of this systematic review was to compare the outcomes used after administration of systemic treatment to organ donors, no meta-analysis of the effects of treatments was undertaken. As part of an exploratory analysis, we also investigated the age, sex and ethnicity representativeness of included trials.

\section{Results}

Our search identified 17,877 records and we assessed 54 full-text articles for exclusion by screening of titles, duplicates and abstracts. Twenty-two RCTs were included in the final analysis (PRISMA, Fig. 1). Twenty-one studies were published in English, and one French study was translated by a native speaking researcher (DM).

The 22 RCTs included a total of 3432 donors. Details of the included studies are shown in Table 1. Twenty-one RCTs were conducted in high income countries across Europe and North America, with one study conducted in Iran (12, 13). Five RCTs evaluated systemic thyroid hormone therapy, four used systemic steroids and two studies used a combination of steroids and thyroid hormone. Further systemic treatments included albuterol, desmopressin, dopamine, protocolised fluid therapy, therapeutic hypothermia, naloxone, phentolamine, simvastatin, vitamin $\mathrm{C}$ or a protocolised ventilation strategy and were studied by one trial each. Almost one third (7/22) of all studies focused primarily on kidney transplantation and a further of eight studies were aimed at optimising donor factors in critical care. Four studies primarily studied lung transplantation, two studied liver transplantation and only one study was primarily aimed at heart transplantation. 
Table 1

Details of included studies, sorted by year of publication

\begin{tabular}{|c|c|c|c|c|c|c|}
\hline $\begin{array}{l}\text { Year of } \\
\text { publication }\end{array}$ & Author & $\begin{array}{l}\text { Primary } \\
\text { organ } \\
\text { of } \\
\text { Interest }\end{array}$ & Intervention & $\begin{array}{l}\text { Number of } \\
\text { randomised } \\
\text { donors }\end{array}$ & $\begin{array}{l}\text { Specified primary } \\
\text { end point }\end{array}$ & $\begin{array}{l}\text { Also published } \\
\text { in as follow up } \\
\text { /nested or } \\
\text { substudy }\end{array}$ \\
\hline 1991 & Mariot (19) & $\begin{array}{l}\text { Donor } \\
\text { stability }\end{array}$ & $\begin{array}{l}\text { (1) T3 } 1 \mathrm{mcg} / \mathrm{ml} \\
\text { and hydrocortisone } \\
50 \mathrm{mg} / \mathrm{ml} ;(2) \\
\text { placebo }\end{array}$ & 40 & $\begin{array}{l}\text { Haemodynamic } \\
\text { stability }\end{array}$ & \\
\hline 1998 & Guesde (48) & Kidney & $\begin{array}{l}\text { (1) Desmopressin } 1 \\
\text { mcg bolus every } 2 \\
\text { hours; }(2) \\
\text { Desmopressin only }\end{array}$ & 97 & $\begin{array}{l}\text { Serum Creatinine, } \\
\text { Delayed Graft } \\
\text { Function }\end{array}$ & \\
\hline 2000 & Polyak(49) & Kidney & $\begin{array}{l}6 \text { arms : } \\
(10 \mathrm{mg} \\
\text { phentolamine/50kg } \\
\text { of phentolamine } \\
\text { mesylate vs. } 20 \mathrm{mg} \\
\mathrm{H} / 50 \mathrm{~kg} \\
\text { hydralazine vs. } \\
\text { standard care) with } \\
\text { cold stage vs. } \\
\text { machine perfusion }\end{array}$ & 150 & $\begin{array}{l}\text { (1) renal flow } \\
\text { characteristics, } \\
\text { (2) DGF }\end{array}$ & \\
\hline 2005 & $\begin{array}{l}\text { Perez- } \\
\text { Blanco(20) }\end{array}$ & $\begin{array}{l}\text { Donor } \\
\text { stability }\end{array}$ & $\begin{array}{l}\text { (1) } 1 \mathrm{mcg} / \mathrm{kg} \mathrm{T3} \\
\text { intravenous bolus, } \\
\text { followed by } 0.06 \\
\mathrm{mcg} / \mathrm{kg} \text { per hour for } \\
270 \mathrm{~min} \text {, to max of } \\
100 \mathrm{mcg} \text {; } \\
\text { (2) Usual care }\end{array}$ & 52 & $\begin{array}{l}\text { Donor stability } \\
\text { and organ } \\
\text { biochemistry }\end{array}$ & \\
\hline 2008 & Kotsch (50) & Liver & $\begin{array}{l}\text { (1) } 250 \mathrm{mg} \\
\text { Methylprednisolone } \\
\text { bolus and } 100 \\
\text { mg/h afterwards; } \\
\text { (2) Usual care }\end{array}$ & 100 & $\begin{array}{l}\text { Liver } \\
\text { biochemistry, } \\
\text { cytokine levels }\end{array}$ & $\begin{array}{l}\text { Pratschke } \\
2006(18)\end{array}$ \\
\hline 2008 & $\begin{array}{l}\text { Venkateswaran } \\
\text { (51) }\end{array}$ & Lung & $\begin{array}{l}\text { (1) } \\
\text { Methylprednisolone } \\
15 \mathrm{mg} / \mathrm{kg}(1 \mathrm{~g}) ; \\
\text { (2) T3 } 0.8 \mathrm{mcg} / \mathrm{kg} \\
\text { bolus following by } \\
\text { infusion }(0.113 \\
\text { mcg/kg/hr); } \\
\text { (3) } \\
\text { Methylprednisolone } \\
\text { + T3; } \\
\text { (4) (4) Placebo }\end{array}$ & 80 & $\begin{array}{l}\text { Difference } \\
\text { between PaO2 } \\
\text { and FiO2 prior to } \\
\text { organ retrieval } \\
\text { (2008); } \\
\text { Difference in } \\
\text { cardiac index } \\
\text { (2009) } \\
\text { Expression of } \\
\text { mRNA on T3 } \\
\text { responsive genes } \\
(2010)\end{array}$ & $\begin{array}{l}\text { Venkateswaran } \\
2009(52) \\
\text { James } \\
2010(22)\end{array}$ \\
\hline
\end{tabular}

Overview of included 22 RCTs including year of publication, primary target of each RCT, details of intervention and comparator and number of randomised donors. For each RCT the listed primary outcome as reported by each study is given. Information about nested, follow-up and/or sub-studies referring to the same donor cohort is also provided. 


\begin{tabular}{|c|c|c|c|c|c|c|}
\hline $\begin{array}{l}\text { Year of } \\
\text { publication }\end{array}$ & Author & $\begin{array}{l}\text { Primary } \\
\text { organ } \\
\text { of } \\
\text { Interest }\end{array}$ & Intervention & $\begin{array}{l}\text { Number of } \\
\text { randomised } \\
\text { donors }\end{array}$ & $\begin{array}{l}\text { Specified primary } \\
\text { end point }\end{array}$ & $\begin{array}{l}\text { Also published } \\
\text { in as follow up } \\
\text { /nested or } \\
\text { substudy }\end{array}$ \\
\hline \multirow[t]{3}{*}{2009} & \multirow[t]{3}{*}{ Schnuelle (53) } & \multirow[t]{3}{*}{ Kidney } & $\begin{array}{l}\text { (1) Dopamine } 4 \\
\mathrm{mcg} / \mathrm{kg} / \mathrm{min} \text {; }\end{array}$ & \multirow[t]{3}{*}{264} & \multirow[t]{3}{*}{$\begin{array}{l}\text { Delayed Graft } \\
\text { Function }\end{array}$} & $\begin{array}{l}\text { Benck } \\
2011(54)\end{array}$ \\
\hline & & & \multirow[t]{2}{*}{ (2) No dopamine } & & & $\begin{array}{l}\text { Benck } \\
2018(55)\end{array}$ \\
\hline & & & & & & $\begin{array}{l}\text { Schnuelle } \\
2017(56)\end{array}$ \\
\hline 2010 & Kainz (57) & Kidney & $\begin{array}{l}\text { (1) } 1 \mathrm{~g} \\
\text { Methylprednisolone; } \\
\text { (2) } 0.9 \% \text { Saline }\end{array}$ & 306 & $\begin{array}{l}\text { DGF (Kainz 2010) } \\
\text { and 5-year graft } \\
\text { survival (Reindl- } \\
\text { Schwaighofer } \\
\text { 2019) }\end{array}$ & $\begin{array}{l}\text { Reindl- } \\
\text { Schwaighofer } \\
2019 \text { (14) }\end{array}$ \\
\hline 2010 & Mascia(23) & Lung & $\begin{array}{l}\text { (1) conventional } \\
\text { ventilatory strategy; } \\
\text { (2) protective } \\
\text { ventilatory strategy }\end{array}$ & 118 & $\begin{array}{l}\text { Number of } \\
\text { potential donors } \\
\text { meeting eligibility }\end{array}$ & \\
\hline \multirow[t]{2}{*}{2012} & Amatschek(25) & Liver & $\begin{array}{l}\text { (1) single injection } \\
\text { of } 1000 \mathrm{mg} \\
\text { methylprednisolone; }\end{array}$ & 90 & \multirow{2}{*}{$\begin{array}{l}\text { Concentration } \\
\text { slope of } \\
\text { transaminase } \\
\text { within } 1 \text { st week } \\
\text { after transplant }\end{array}$} & \\
\hline & & & $\begin{array}{l}\text { (2) placebo }(0.9 \% \\
\text { saline) injection } \\
\text { between } 6 \text { and } 3 \mathrm{~h} \\
\text { before organ } \\
\text { recovery }\end{array}$ & & & \\
\hline 2013 & Sharpe(16) & $\begin{array}{l}\text { Donor } \\
\text { factors }\end{array}$ & $\begin{array}{l}\text { (1) Oral T4 (2 } \\
\mathrm{mcg} / \mathrm{kg}) ;(2) \\
\text { intravenous }\end{array}$ & 32 & $\begin{array}{l}\text { Percentage of } \\
\text { study time donors } \\
\text { required inotropic } \\
\text { support }\end{array}$ & \\
\hline \multirow[t]{2}{*}{2014} & Ware (42) & Lung & $\begin{array}{l}\text { (1) Aerosolized } \\
\text { albuterol (5 mg 4- } \\
\text { hourly); }\end{array}$ & 506 & \multirow{2}{*}{$\begin{array}{l}\text { Change in } \\
\text { oxygenation from } \\
\text { enrolment to } \\
\text { organ } \\
\text { procurement }\end{array}$} & \\
\hline & & & (2) Placebo & & & \\
\hline \multirow[t]{2}{*}{2015} & Niemann(58) & Kidney & $\begin{array}{l}\text { (1) Hypothermia } \\
(34-35 \text { degrees) for } \\
4 \text { hours; }\end{array}$ & 370 & \multirow[t]{2}{*}{$\begin{array}{l}\text { Delayed Graft } \\
\text { Function }\end{array}$} & \\
\hline & & & $\begin{array}{l}\text { (2) Normothermia } \\
(36.5-37.5) \text { for } 4 \\
\text { hours }\end{array}$ & & & \\
\hline \multirow[t]{2}{*}{2015} & Orban(12) & Kidney & $\begin{array}{l}\text { (1) } 600 \mathrm{mg} \text { of IV N- } \\
\text { Acetylcysteine ( } 1 \mathrm{hr} \\
\text { prior to and } 2 \text { hours } \\
\text { post cerebral } \\
\text { angiography); }\end{array}$ & 217 & \multirow[t]{2}{*}{$\begin{array}{l}\text { Delayed Graft } \\
\text { Function }\end{array}$} & \\
\hline & & & $\begin{array}{l}\text { (2) No N- } \\
\text { Acetylcysteine }\end{array}$ & & & \\
\hline
\end{tabular}

Overview of included 22 RCTs including year of publication, primary target of each RCT, details of intervention and comparator and number of randomised donors. For each RCT the listed primary outcome as reported by each study is given. Information about nested, follow-up and/or sub-studies referring to the same donor cohort is also provided. 


\begin{tabular}{|c|c|c|c|c|c|c|}
\hline $\begin{array}{l}\text { Year of } \\
\text { publication }\end{array}$ & Author & $\begin{array}{l}\text { Primary } \\
\text { organ } \\
\text { of } \\
\text { Interest }\end{array}$ & Intervention & $\begin{array}{l}\text { Number of } \\
\text { randomised } \\
\text { donors }\end{array}$ & $\begin{array}{l}\text { Specified primary } \\
\text { end point }\end{array}$ & $\begin{array}{l}\text { Also published } \\
\text { in as follow up } \\
\text { /nested or } \\
\text { substudy }\end{array}$ \\
\hline 2015 & Kazemi (13) & $\begin{array}{l}\text { Donor } \\
\text { factors } \\
\text { (2015), } \\
\text { liver } \\
(2016)\end{array}$ & $\begin{array}{l}\text { (1) } 100 \mathrm{mg} / \mathrm{kg} \text { dose } \\
\text { of vitamin C } 6 \\
\text { hours before } \\
\text { procurement } \\
\text { followed by vitamin } \\
\mathrm{C} \text { infusion ( } 100 \\
\mathrm{mg} / \mathrm{kg} \text { ) over the } 6 \\
\text { hours; } \\
\text { (2) standard care }\end{array}$ & 40 & $\begin{array}{l}\text { (1) donor IL-6, } \\
\text { donor TNF-alpha } \\
\text { gene expression; } \\
\text { (2) recipient liver } \\
\text { function (2015) } \\
\text { Inflammatory } \\
\text { cytokine levels } \\
\text { (2016) }\end{array}$ & $\begin{array}{l}\text { Sisakth } \\
2016(26)\end{array}$ \\
\hline 2015 & Al-Khafaji(59) & $\begin{array}{l}\text { Donor } \\
\text { factors }\end{array}$ & $\begin{array}{l}\text { (1) Protocolised } \\
\text { fluid therapy; } \\
\text { (2) Usual care }\end{array}$ & 556 & $\begin{array}{l}\text { Number of } \\
\text { organs } \\
\text { transplanted per } \\
\text { donor }\end{array}$ & \\
\hline 2018 & Jafari(60) & Kidney & $\begin{array}{l}\text { (1) } \\
\text { Methylprednisolone } \\
15 \mathrm{mg} / \mathrm{kg} \text { day; } \\
\text { (2) } \\
\text { Methylprednisolone } \\
15 \mathrm{mg} / \mathrm{kg} / \text { day + } \\
100 \mathrm{mg} 2 \text {-hourly; } \\
\text { (3) Usual care }\end{array}$ & 51 & $\begin{array}{l}\text { Expression of } \\
\text { inflammatory } \\
\text { mediators and } \\
\text { toll-like receptors }\end{array}$ & \\
\hline 2018 & Holmstrom (61) & Heart & $\begin{array}{l}\text { (1) } 80 \text { mg } \\
\text { simvastatin; (2) } \\
\text { Control }\end{array}$ & 84 & $\begin{array}{l}\text { Recipient TnT (or } \\
\text { Trop-l, or CK-MB) }\end{array}$ & $\begin{array}{l}\text { Nykanen } \\
2019(27)\end{array}$ \\
\hline 2019 & Dhar(17) & $\begin{array}{l}\text { Donor } \\
\text { factors }\end{array}$ & $\begin{array}{l}\text { (1) T3 } 4 \mathrm{mcg} \text { bolus } \\
\text { then } 2 \mathrm{mcg} / \mathrm{h} \text {; } \\
\text { (2) T4 } 20 \mathrm{mcg} \text { bolus, } \\
\text { then } 10 \mathrm{mcg} / \mathrm{h}\end{array}$ & 37 & $\begin{array}{l}\text { LVEF } \\
\text { (Echocardiogram) }\end{array}$ & \\
\hline 2019 & Dhar(62) & Lung & $\begin{array}{l}\text { (1) Naloxone } 8 \mathrm{mg} \text {; } \\
\text { (2) } 0.9 \% \text { Saline }\end{array}$ & 199 & $\begin{array}{l}\text { Change in } \\
\text { fraction of } \\
\text { inspired oxygen } \\
\text { ratio from } \\
\text { baseline to final } \\
\text { arterial gas }\end{array}$ & \\
\hline 2019 & Frenette(62) & $\begin{array}{l}\text { Donor } \\
\text { factors }\end{array}$ & $\begin{array}{l}\text { (1) Levothyroxine } \\
20 \text { mcg bolus } \\
\text { followed by } 20 \\
\text { mcg/hr infusion; } \\
\text { (2) Placebo }\end{array}$ & 15 & $\begin{array}{l}\text { Feasibility } \\
\text { outcomes }\end{array}$ & \\
\hline \multirow[t]{2}{*}{2020} & Dhar(28) & $\begin{array}{l}\text { Donor } \\
\text { factors }\end{array}$ & $\begin{array}{l}\text { (1) Levothyroxine } \\
20 \text { mcg bolus } \\
\text { followed by } 10 \\
\text { mcg/hr infusion; } \\
\text { (2) Placebo }\end{array}$ & 28 & $\begin{array}{l}\text { LVEF } \\
\text { (Echocardiogram) }\end{array}$ & \\
\hline & & & $\begin{array}{l}\text { total number of } \\
\text { donors }\end{array}$ & 3432 & & \\
\hline $\begin{array}{l}\text { Overview of } \\
\text { comparator } \\
\text { given. Inforn }\end{array}$ & $\begin{array}{l}\text { cluded } 22 \text { RCTs it } \\
\text { dd number of ranc } \\
\text { tion about nestec }\end{array}$ & $\begin{array}{l}\text { uding ye } \\
\text { nised do } \\
\text { ollow-up }\end{array}$ & $\begin{array}{l}\text { of publication, prima } \\
\text { rs. For each RCT the } \\
\text { d/or sub-studies refe }\end{array}$ & $\begin{array}{l}\text { target of eac } \\
\text { ted primary c } \\
\text { ng to the san }\end{array}$ & $\begin{array}{l}\text { CT, details of interv } \\
\text { come as reported b } \\
\text { donor cohort is als }\end{array}$ & $\begin{array}{l}\text { tion and } \\
\text { each study is } \\
\text { rovided. }\end{array}$ \\
\hline
\end{tabular}




\section{Risk of bias in included studies}

All twenty two trials were assessed for risk of bias, with eight at high risk of bias (Fig. 2). Only one trial was at low risk of bias(14). Approximately a quarter of all studies were at high risk of reporting and performance bias. Further details of risk of bias assessments can be found in Additional file 3.

\section{Synthesis of results}

\section{Multitude of reported outcomes across studies}

Eight RCTs (36.3\%) aimed to study the effects of the intervention on outcomes directly relevant during the donor management period in ICU. Amongst this group, named outcomes included: vasopressor/inotrope requirements, echocardiography parameters, number of transplanted organs, routine biochemical (e.g. thyroid function) or inflammatory (e.g. TNF-alpha) markers, or an assessment of haemodynamic stability. The remaining fourteen studies identified one transplanted organ as their main target, with the kidney $(n=7)$ as the most studied graft, followed by lungs $(n=4)$, liver $(n=$ 2 ) and heart $(n=1)$. Amongst each of these, there was variation of the exact outcomes measured. Effects of treatments on pancreas were only studied in one trial (15), whilst simultaneous kidney and pancreas and intestinal transplants were not studies in any of the trials.

Renal outcomes included post-transplant serum creatinine levels, presence of delayed graft function (DGF, defined as need for dialysis in first week post-transplant), primary non-function or biopsy-proved graft failure. Similar variability in organ outcomes was seen for studies focusing on the liver (post-transplant biochemical assessment versus record of graft function) or heart (echocardiogram assessment versus record of graft function) transplantation. All four studies of lung outcomes chose graft function before retrieval as their main outcome measure, whether by recording the number of lungs available for transplant or by reporting pre-specified outcomes such as final arterial blood gas or FiO2 prior to organ procurement $(14,16-18)$. One study of lung transplants reported one year survival of recipients of other organs, although no record of graft function or survival was made (16). The duration of follow up also significantly varied: ranging from reporting only outcomes before procurement (during duration of donor management) to trials with 5-year follow up, often published separately.

\section{Outcomes by studied intervention}

All included RCTs administered systemic treatment(s) to the randomised donor. Eleven studies studied the effects of steroids and/or thyroid hormone. The reported outcomes were grouped into outcomes affecting the major transplanted organs (kidney, liver, heart, lungs) or donor factors (such as factors haemodynamic stability or number of organs accepted for procurement). Figure 3 demonstrates that nearly all studies (21/22) of systemic treatments do not report outcome data across all the outcome domains. Only one study comparing ventilation strategies of the donor covered all outcome groups, albeit only reporting the recipient survival for each of the major transplanted organs (14). Overall, the kidney or donor factor outcome groups were most often included, with each contributing to seven intervention types. DGF was the most common reported renal outcome (6/7 studies), whilst donor factors included a variety of different outcomes such as number of transplanted organs, inotrope or vasopressor requirement, left ventricular ejection fraction or cardiac index.

\section{Outcomes by studied primary organ}

Many of the selected outcomes depended on the primary target, e.g. kidney or physiological measurements in ICU. Studies focusing on kidney or heart transplantation were more likely to provide a more comprehensive assessment of other organs, as displayed in Fig. 4. Early outcomes - defined as within 30 days of transplantation - more commonly reported surrogate outcomes such as changes in laboratory markers or echocardiographic function. Trials of interventions aimed at donor stability only rarely assessed organ specific function or outcomes - such as pre-transplant lung function, biochemical liver 
function assessment or mention of primary graft dysfunction for cardiac allografts. Furthermore, none of the donor stability RCTs assessed any long-term recipient or graft outcomes; therefore the long term effects of systemic treatment administered to nearly a quarter of all donors $(23.3 \%, 800 / 3432)$ have not been collected by included trials. Organ-focused trials included long-term follow up of either one, three or five years of graft survival and between six months and three years of recipient survival as shown in Fig. 5. Only one study reported the incidence of long term post-transplant complications relating to immunosuppression, such as post-transplant lymphoproliferative disease (15). More specific measures of long term graft function after transplantation (such as creatinine or liver function tests) were only assessed in two studies $(19,20)$. Organ specific rejection at 30 days and 3 months was studied in two trials aimed at the kidney $(21,22)$. Rejection episodes within 6 or 3 years follow up were reported in both trials aimed at the liver $(20,23)$. No studies reported on health-related quality of life in recipients of transplanted organs.

\section{Exploratory analysis - Donor and recipient age, sex and ethnicity}

In the UK, the NHS Blood and Transplant 2018-19 report describes the characteristics of 962 donors during that period: on average $51+/-16$ years of age, mostly white (865/962, 90\%) with an equal distribution of male (49\%) and female (51\%) donors. Only a minority of donors were reported as Asian (4\%), Black (2\%) or 'other ethnicity' (4\%) (3). All included studies provide the age of the included donors, however the trial donor population is on average a decade younger than the average UK donor; In eight studies the average donor age was below 40 years and in 12 studies the average age was under 50 years. Donor sex information is available for $n=2669$ donors in total (20 studies) with $1596(59.8 \%)$ male and $1073(40.2 \%)$ female donors. Some individual studies, however, had groups more heavily skewed towards male donors $(15,17,24,25)$. Donor ethnicity was reported by three studies only $(16,17,26)$, with two further studies $(27,28)$ reporting the percentage of AfroAmerican donors in the two groups. The three studies which provide a breakdown of donor ethnicity describe a study population of between $60-80 \%$ white donors. Nine studies provide sex or age information for the recipients of the donated organs, whilst information on recipient ethnicity is not reported by any of the included trials.

\section{Discussion}

\section{Key findings}

The main findings from this systematic review are:

(a) there are a multitude of different early and long term outcomes studied;

(b) beneficial or harmful effects of systemic treatments are not studied across all donated organs;

(c) recipient-centred outcomes are mostly limited to duration of graft and/or recipient survival

(d) donor and recipient age, sex and ethnicity are not consistently reported across all trials

To date systematic reviews of effects of donor interventions have failed to demonstrate a benefit for any identified treatment (29-31). Published meta-analyses often demonstrate small number of identified trials and high heterogeneity. This systematic review set out to identify outcomes studied in the context of donor management research. Identified studies focus mostly on single organ outcomes or outcomes relating to donor stability without assessing if (or how) this translates to improved graft function or graft and recipient survival. The included studies can be grouped together either by studied intervention (e.g. steroids) or by the primary identified target (e.g. kidney).

Many of the selected outcomes appear to depend on the intended primary target organ of each study rather than the selected treatment. Therefore, grouping the trials by intervention alone does not provide a complete picture. The plots of outcomes by intended primary target organ or donor stability (Figs. 4 and 5) analyse the published outcomes further, comparing early outcomes (within 30 days) and long-term outcomes and duration of follow up. Studies primarily focused on kidney or heart transplantation provide more comprehensive assessment of early outcomes relating to other organs. Studies mainly focused 
on donor factors/stability fail to assess many early outcomes relating to transplanted organs other than liver function tests. In addition, they fail to assess whether the interventions aimed to improve donor stability translate to long-term benefits for any of the recipients of transplanted organs. Early outcomes for kidney, liver and heart transplants mostly report surrogate outcomes such as biochemical serum levels or function recorded on echocardiogram. All four included studies of donor management in lung transplantation only report a measure of graft function before procurement but not after transplantation. Lung transplant recipient survival is only assessed in one of those studies, at limited to a follow up period of six months.

With an increased interest in donor management research reflected by the increasing numbers of clinical trials and the increasing demand for organs, there is a need for standardisation or creation of a core outcome set for donor management research as has been done in other settings $((32,33)$. Any such discussion would benefit from involvement of donor families, potential donors registered on donor lists in different countries and recipients - both on the waiting list and post-transplant. The use of studies within a trial (SWATs) as part of future donor management research could be used to further explore individual aspects of trial design in this acute setting.

Performing large clinical trials in this setting are challenging to conduct and pose logistical and ethical challenges. The increasing number of studies of donor management research across the studied years shows that this is a rapidly evolving research area. The prevention of organ injury by influencing the balance of pro- and anti-inflammatory mediators, targeting ischaemia-reperfusion and studying the role of the immune response to target recovery and repair has been studies in many pre-clinical settings (34-39). However, there is limited translation of research of prevention of organ injury (and promotion of repair or recovery) into clinical practice during the period of donor management. The majority of guidelines regarding organ donor management are based on ICU management of critically unwell adults (6).

Each donor can potentially donate multiple organs, thus the effects of systemic interventions on each of the organs are important. Whilst novel treatments might not translate into a benefit for all grafts and recipients of those organs, it is important to demonstrate that systemic treatments are at least safe and do not impair the ability to procure and transplant other organs. This is in contrast with the multitude of recent and ongoing studies of ex vivo machine perfusion demonstrating benefits at individual organ level $(40,41)$. Niemann et al used a six month safety period during the mild hypothermia study to monitor that lowering the donor body temperature does not inadvertently affect thoracic organs however this was not assessed as an outcome of the study(42). The available donor pool across all nations is still by far outnumbered by long waiting lists, therefore novel treatments should not omit to demonstrate their impact on every transplantable organ. In addition, demonstrating a benefit in more than just one organ group might give the proposed treatment more weight. To complicate matters from a methodological point of view, we noted that only $4 / 21$ studies explicitly considered to seek consent from the recipients of the organs procured after donor intervention (24); only one of the included studies did indeed seek recipient consent (43).

Whilst outcome measures formed the mainstay of this review, two main methodological problems were identified during the appraisal of the included studies. Donor and recipient characteristics such as ethnicity and sex are not reported in a standardised manner across the studies. Both aspects matter beyond the concept of missing data and minutiae of trial methodology. Steroids are amongst the most studied interventions to improve donation outcomes, their role has also been previously often debated in the context of critical illness. Several studies of the use of steroids in sepsis have been undertaken(44) yet a definite protective role to change clinical practice has not been proven beyond a reasonable doubt. Critical care trials are inherently difficult due to a heterogenous, often multi-morbid population and it may simply be that any beneficial effect is too small to be observed under such circumstances. This translates to trials of treatment of the brain dead donor, with a variety of different underlying pathologies across the study population. The COVID-19 pandemic offered a first opportunity to study the role of steroids for one defined pathology within the critical care population and the results of the RECOVERY trial confirmed a beneficial role for dexamethasone for patients requiring oxygen or respiratory support (4547). Both biological sex as well as ethnicity (amongst other factors) are suggested to play a role in contributing to the shape of the inflammatory response during severe illness (9). The contribution of such donor factors to their inflammatory response 
and how it could be shaped by treatments, is therefore an important factor to consider and ought to be routinely reported for the donor (and recipient) population in donor management studies. The latest NHS Blood and Transplant data shows that up to $31 \%$ of patients on the waiting list in the UK are from a black, Asian or minority ethnic background and spend a longer time on the waiting list than white patients. Understanding how to improve the quality and outcome of organs from ethnic minority donors - or for ethnic minority recipients - will have a big impact.

The strength of the review is the strict methodological process. Our review protocol was prospectively registered, we followed Cochrane Collaboration and PRISMA recommendations, performed a comprehensive search and carried out duplicate data extraction and risk of bias assessments. The limitations to the conclusions of this systematic review can be attributed to the clinical and methodological differences between the trials. We focused on donor interventions only, and therefore potentially promising treatment strategies of the graft after procurement and during preservation, that may be of a pre-transplant treatment potential, were excluded.

\section{Conclusions}

This systematic review provides a first and an up-to-date systematic overview of all outcomes studied in RCTs of systemic treatments or interventions to the organ donor. Across the included RCTs, there was a wide range of outcomes that can be subdivided into donor stability factors, graft outcomes (early or late) and recipient outcomes. Not only did the majority of studies limit their selected outcomes mostly to their target domain, even within each domain there was a distinct absence of agreement about the exact outcome parameters or duration of follow up, e.g. a distinct lack of recipient-centred outcomes, such as health-related quality of life. The urgent need to improve organ utilisation to reduce mortality on the waiting lists for transplantation in the UK and Europe is nowadays addressed with an increased drive to develop methodologies for RCTs that evaluate targeted interventions in deceased donors after confirmation of brain death. Interventions that succeed in preventing or at least reducing injury of organs will increase the available organ pool for successful transplantation leading to prolonged survival of organs and patients. The results of this review can be used as a basis for future priority setting exercises, developing core outcome sets and to guide future donor management research.

\section{Abbreviations}

CK-MB - Creatine Kinase Myocardial Band

DBD - Donation after Brain Death

DGF - Delayed graft function

FiO2 - fraction of inspired oxygen

ICU - Intensive care units

IL-6 - interleukin-6

IV - intravenous

LVEF - left ventricular ejection fraction

mcg - microgram

mg - milligram

RCTs - Randomised control trials

$\mathrm{PaO} 2$ - partial pressure of oxygen

Page $11 / 22$ 
T3 - triiodothyronine

T4 - thyroxine

TnT - Troponin T

TNF - Tumour Necrosis Factor

Trop-I - Troponin I

SWAT - Study within a Trial

\section{Declarations}

\section{Ethics approval and consent to participate}

Not applicable

\section{Consent for publication}

Not applicable

\section{Availability of data and materials}

Full details of the search strategy are included as Additional file 2. The datasets used and/or analysed during the current study are available from the corresponding author on reasonable request

\section{Competing interests}

AS is currently supported by a National Institute for Health Research Doctoral Research Fellowship (NIHR-DRF-2017-10-094).

RJP is the PI for the Quality in Organ Donation programme.

The remaining authors declare they have no competing interests.

\section{Funding}

None

\section{Authors' contributions}

$\mathrm{KDB}, \mathrm{MRE}$ and AS contributed to the search of the scientific literature, data collection and risk of bias assessment of the included studies. KDB and AS contributed to the conception and design of the systematic review. KDB led data analysis, interpretation and drafted the initial version of the manuscript. RJP contributed to the conception, manuscript revision for critical intellectual content and supervision of the review. All authors read and approved the final manuscript.

\section{Acknowledgements}

The authors would like to thank Dr David Menassa for help with translation of one of the included RCTs.

\section{References}

1. Eurotransplant. Eurotransplant Report 2019. 
2. Eurotransplant. Eurotransplant Report 2018 [Internet]. 2018. Available from: https://www.eurotransplant.org/wpcontent/uploads/2019/12/032675-_ET_Jaarverslag_2018_v7-1.pdf

3. Transplant NB and. Organ Donation and Transplantation Activity Report 2018/19 [Internet]. 2019. Available from: https://nhsbtdbe.blob.core.windows.net/umbraco-assets-corp/16537/organ-donation-and-transplantation-activityreport-2018-2019.pdf

4. Meyfroidt G, Gunst J, Martin-Loeches I, Smith M, Robba C, Taccone FS, et al. Management of the brain-dead donor in the ICU: general and specific therapy to improve transplantable organ quality. Intensive Care Medicine [Internet]. 2019;45(3):343-53. Available from: https://doi.org/10.1007/s00134-019-05551-y

5. Bera KD, Shah A, English MR, Harvey D, Ploeg RJ. Optimisation of the organ donor and effects on transplanted organs: a narrative review on current practice and future directions. Vol. 75, Anaesthesia. Blackwell Publishing Ltd; 2020. p. 1191204.

6. NHS Blood and Transplant. Donor optimisation. Guidance around selecting potential DBD donors. 2012. [Internet]. 2012 [cited 2021 Feb 2]. Available from: https://www.odt.nhs.uk/deceased-donation/best-practice-guidance/donoroptimisation/

7. NHSBT NB and T. Organ donation and transplantation - Activity Report 2019/20 [Internet]. 2020. Available from: https://nhsbtdbe.blob.core.windows.net/umbraco-assets-corp/19481/activity-report-2019-2020.pdf

8. Moher D, Liberati A, Tetzlaff J, Altman DG. Preferred reporting items for systematic reviews and meta-analyses: The PRISMA statement. BMJ (Online). 2009.

9. Mariot J, Jacob F, Voltz C, Perrier JF, Strub P. Intérêt de l'hormonothérapie associant triiodothyronine et cortisone chez le patient en état de mort cérébrale. Annales francaises d'anesthesie et de reanimation. 1991;

10. Higgins JPT, Altman DG, Gøtzsche PC, Jüni P, Moher D, Oxman AD, et al. The Cochrane Collaboration's tool for assessing risk of bias in randomised trials. BMJ (Online). 2011;

11. The Nordic Cochrane Centre. Review Manager (RevMan). Cochrane Collaboration. 2014;

12. Kazemi M, Tabei SMB, Najafizadeh K, Sisakht JM, Milani S, Khosravi MB. Evaluation of the Effect of Ascorbic Acid Administration on Gene Expression Level of IL-6 and TNF-a Cytokines in Deceased Donors. Iranian Journal of Allergy, Asthma and Immunology [Internet]. 2015;14(2):149-57. Available from:

http://ijaai.tums.ac.ir/index.php/ijaai/article/view/399

13. Mehrabi Sisakht J, Khosravi MB, Milani S, Kazemi M, Tabei SMB. Evaluation of gene expression pattern of il1 b and il10 cytokines following vitamin c administration among brain-dead liver donors. Iranian Red Crescent Medical Journal. 2016;

14. Mascia L, Pasero D, Slutsky AS, Arguis MJ, Berardino M, Grasso S, et al. Effect of a lung protective strategy for organ donors on eligibility and availability of lungs for transplantation: A randomized controlled trial. JAMA - Journal of the American Medical Association. 2010;

15. Nykanen Al, Holmström E, Syrjälä S, Jokinen J, Krebs R, Lemström KB. Effect of Donor Simvastatin Treatment on Cardiac Allograft Ischemia-Reperfusion Injury - 30-Day Analysis of a Randomized Prospective Single-Center Clinical Trial. The Journal of Heart and Lung Transplantation. 2017;

16. Ware LB, Landeck M, Koyama T, Zhao Z, Singer J, Kern R, et al. A randomized trial of the effects of nebulized albuterol on pulmonary edema in brain-dead organ donors. American Journal of Transplantation. 2014;

17. Dhar R, Paramesh A, Marklin G. A Randomized Controlled Trial of Naloxone for Optimization of Hypoxemia in Lung Donors. The Journal of Heart and Lung Transplantation. 2018;

18. Venkateswaran R v., Patchell VB, Wilson IC, Mascaro JG, Thompson RD, Quinn DW, et al. Early Donor Management Increases the Retrieval Rate of Lungs for Transplantation. Annals of Thoracic Surgery. 2008;

19. Guesde R, Barrou B, Leblanc I, Ourahma S, Goarin JP, Coriat P, et al. Administration of desmopressin in brain-dead donors and renal function in kidney recipients. Lancet. 1998;

Page 13/22 
20. Kotsch K, Ulrich F, Reutzel-Selke A, Pascher A, Faber W, Warnick P, et al. Methylprednisolone therapy in deceased donors reduces inflammation in the donor liver and improves outcome after liver transplantation a prospective randomized controlled trial. Annals of Surgery. 2008;

21. Kainz A, Wilflingseder J, Mitterbauer C, Haller M, Burghuber C, Perco P, et al. Steroid Pretreatment of Organ Donors to Prevent Postischemic Renal Allograft FailureA Randomized, Controlled Trial. Annals of Internal Medicine [Internet]. 2010 Aug 17;153(4):222-30. Available from: http://annals.org/article.aspx?doi=10.7326/0003-4819-153-4-201008170-00003

22. Schnuelle P, Gottmann U, Hoeger S, Boesebeck D, Lauchart W, Weiss C, et al. Effects of donor pretreatment with dopamine on graft function after kidney transplantation: A randomized controlled trial. JAMA - Journal of the American Medical Association. 2009;

23. Amatschek S, Wilflingseder J, Pones M, Kainz A, Bodingbauer M, Mühlbacher F, et al. The effect of steroid pretreatment of deceased organ donors on liver allograft function: A blinded randomized placebo-controlled trial. Journal of Hepatology. 2012;

24. Orban JC, Quintard H, Cassuto E, Jambou P, Samat-Long C, Ichai C. Effect of N-acetylcysteine pretreatment of deceased organ donors on renal allograft function: A randomized controlled trial. Transplantation. 2015;

25. Sharpe MD, van Rassel B, Haddara W. Oral and intravenous thyroxine (T4) achieve comparable serum levels for hormonal resuscitation protocol in organ donors: A randomized double-blinded study. Canadian Journal of Anesthesia. 2013;

26. Al-Khafaji A, Elder M, Lebovitz DJ, Murugan R, Souter M, Stuart S, et al. Protocolized fluid therapy in brain-dead donors: the multicenter randomized MOnIToR trial. Intensive Care Medicine. 2015;

27. Dhar R, Stahlschmidt E, Yan Y, Marklin G. A randomized trial comparing triiodothyronine (T3) with thyroxine (T4) for hemodynamically unstable brain-dead organ donors. Clinical Transplantation. 2019;

28. Dhar R, Stahlschmidt E, Marklin G. A Randomized Trial of Intravenous Thyroxine for Brain-Dead Organ Donors With Impaired Cardiac Function. Progress in Transplantation. 2020;

29. van Erp AC, van Dullemen LFA, Ploeg RJ, Leuvenink HGD. Systematic review on the treatment of deceased organ donors. Transplantation Reviews. 2018.

30. D'Aragon F, Belley-Cote E, Agarwal A, Frenette AJ, Lamontagne F, Guyatt G, et al. Effect of corticosteroid administration on neurologically deceased organ donors and transplant recipients: A systematic review and meta-analysis. BMJ Open. 2017;7(6):1-9.

31. Dupuis S, Amiel JA, Desgroseilliers M, Williamson DR, Thiboutot Z, Serri K, et al. Corticosteroids in the management of brain-dead potential organ donors: A systematic review. British Journal of Anaesthesia. 2014.

32. Sinha IP, Gallagher R, Williamson PR, Smyth RL. Development of a core outcome set for clinical trials in childhood asthma: a survey of clinicians, parents, and young people. Trials. 2012;

33. Kirwan JR, Hewlett SE, Heiberg T, Hughes RA, Carr M, Hehir M, et al. Incorporating the patient perspective into outcome assessment in rheumatoid arthritis - Progress at OMERACT 7. In: Journal of Rheumatology. 2005.

34. Floerchinger B, Oberhuber R, Tullius SG. Effects of brain death on organ quality and transplant outcome. Transplantation reviews (Orlando, Fla) [Internet]. 2012;26(2):54-9. Available from: http://eutils.ncbi.nlm.nih.gov/entrez/eutils/elink.fcgi? dbfrom=pubmed\&amp;id=22459036\&amp;retmode=ref\&amp;cmd=prlinks

35. Jager NM, van Zanden JE, Subías M, Leuvenink HGD, Daha MR, Rodríguez de Córdoba S, et al. Blocking Complement Factor B Activation Reduces Renal Injury and Inflammation in a Rat Brain Death Model. Frontiers in immunology. 2019;10(November):2528.

36. Tillet S, Giraud S, Delpech PO, Thuillier R, Ameteau V, Goujon JM, et al. Kidney graft outcome using an anti-Xa therapeutic strategy in an experimental model of severe ischaemia-reperfusion injury. The British journal of surgery [Internet]. 2015 Jan 1;102(1):132-42-discussion 142. Available from: http://doi.wiley.com/10.1002/bjs.9662

37. Giraud S, Kerforne T, Zely J, Couturier P, Tauc M, Hauet T. Preventive GC7 reduces brain death-induced renal injuries in a preclinical kidney transplantation porcine model. Transplant International. 2019;

Page $14 / 22$ 
38. Chen S, Fang H, Li J, Shi J hua, Zhang J, Wen P, et al. Donor Brain Death Leads to a Worse Ischemia-Reperfusion Injury and Biliary Injury After Liver Transplantation in Rats. Transplantation Proceedings. 2020;

39. Akhtar MZ, Huang H, Kaisar M, lo Faro ML, Rebolledo R, Morten K, et al. Using an Integrated -Omics Approach to Identify Key Cellular Processes That Are Disturbed in the Kidney After Brain Death. American journal of transplantation: official journal of the American Society of Transplantation and the American Society of Transplant Surgeons [Internet]. 2016 May 1;16(5):1421-40. Available from: http://doi.wiley.com/10.1111/ajt.13626

40. Nasralla D, Coussios CC, Mergental H, Akhtar MZ, Butler AJ, Ceresa CDL, et al. A randomized trial of normothermic preservation in liver transplantation. Nature. 2018;

41. Jochmans I, Brat A, Davies L, Hofker HS, van de Leemkolk FEM, Leuvenink HGD, et al. Oxygenated versus standard cold perfusion preservation in kidney transplantation (COMPARE): a randomised, double-blind, paired, phase 3 trial. Lancet (London, England). 2020;

42. Niemann CU, Feiner J, Swain S, Bunting S, Friedman M, Crutchfield M, et al. Therapeutic Hypothermia in Deceased Organ Donors and Kidney-Graft Function. New England Journal of Medicine. 2015;

43. Fang F, Zhang Y, Tang J, Lunsford LD, Li T, Tang R, et al. Association of Corticosteroid Treatment with Outcomes in Adult Patients with Sepsis: A Systematic Review and Meta-analysis. JAMA Internal Medicine. 2019.

44. Dexamethasone in Hospitalized Patients with Covid-19 - Preliminary Report. New England Journal of Medicine. 2020;

45. Jones JM, Fingar KR, Miller MA, Coffey R, Barrett M, Flottemesch T, et al. Racial disparities in sepsis-related in-hospital mortality: Using a broad case capture method and multivariate controls for clinical and hospital variables, 2004-2013. Critical Care Medicine. 2017;

46. Pietropaoli AP, Glance LG, Oakes D, Fisher SG. Gender differences in mortality in patients with severe sepsis or septic shock. Gender medicine. 2010;

47. Thompson K, Venkatesh B, Hammond N, Taylor C, Finfer S, on behalf of the ADRENAL Investigators sex-disaggregated analysis SC. Sex differences in response to adjunctive corticosteroid treatment for patients with septic shock. Intensive care medicine [Internet]. 2021 Jan 7; Available from: http://www.ncbi.nlm.nih.gov/pubmed/33415351

48. Polyak MMR, O’Mar Arrington B, Kapur S, Stubenbord WT, Kinkhabwala M. Donor treatment with phentolamine mesylate improves machine preservation dynamics and early renal allograft function. Transplantation. 2000;

49. Pérez-Blanco A, Caturla-Such J, Cánovas-Robles J, Sanchez-Payá J. Eficiency of triiodothyronine treatment on organ donor hemodynamic management and adenine nucleotide concentration. Intensive Care Medicine. 2005;

50. Pratschke J, ; Kuecuek, Onur; Lun, Andreas; Faber, Wladimir; Weiss, Sascha; Kotsch, Katja; Pascher, Andreas; Ulrich, Frank; Jonas, Sven; Wesslau, claus; Tullius S. SIGNIFICANT REDUCTION OF PROINFLAMMATORY CYTOKINES BY TREATMENT OF THE HUMAN BRAIN DEAD DONOR - A PROSPECTIVE RANDOMIZED TRIAL. In: Transplantation. 2006.

51. Venkateswaran R v., Dronavalli V, Lambert PA, Steeds RP, Wilson IC, Thompson RD, et al. The proinflammatory environment in potential heart and lung donors: Prevalence and impact of donor management and hormonal therapy. Transplantation. 2009;

52. James SR, Ranasinghe AM, Venkateswaran R, McCabe CJ, Franklyn JA, Bonser RS. The effects of acute triiodothyronine therapy on myocardial gene expression in brain stem dead cardiac donors. Journal of Clinical Endocrinology and Metabolism. 2010;

53. Benck U, Gottmann U, Hoeger S, Lammert A, Rose D, Boesebeck D, et al. Donor desmopressin is associated with superior graft survival after kidney transplantation. Transplantation. 2011;

54. Benck U, Jung M, Krüger B, Grimm A, Weiss C, Yard BA, et al. Donor Dopamine Does Not Affect Liver Graft Survival: Evidence of Safety From a Randomized Controlled Trial. Liver Transplantation. 2018;

55. Schnuelle P, Schmitt WH, Weiss C, Habicht A, Renders L, Zeier M, et al. Effects of dopamine donor pretreatment on graft survival after kidney transplantation: A randomized trial. Clinical Journal of the American Society of Nephrology. 2017; 
56. Kainz A, Wilflingseder J, Mitterbauer C, Haller M, Burghuber C, Perco P, et al. Steroid pretreatment of organ donors to prevent postischemic renal allograft failure: A randomized, controlled trial. Annals of Internal Medicine. 2010;

57. Reindl-Schwaighofer R, Kainz A, Jelencsics K, Heinzel A, Berlakovich G, Remport Á, et al. Steroid pretreatment of organ donors does not impact on early rejection and long-term kidney allograft survival: Results from a multicenter randomized, controlled trial. American Journal of Transplantation. 2019;

58. Orban J-C, Quintard H, Cassuto E, Jambou P, Samat-Long C, Ichai C. Effect of N-Acetylcysteine Pretreatment of Deceased Organ Donors on Renal Allograft Function: A Randomized Controlled Trial. Transplantation [Internet]. 2015;99(4):74653. Available from: http://content.wkhealth.com/linkback/openurl?sid=WKPTLP:landingpage\&amp;an=00007890201504000-00018

59. Jafari R, Aflatoonian R, Falak R, Pourmand G, Dehghani S, Mortazavi M, et al. Down-regulation of inflammatory signaling pathways despite up-regulation of Toll-like receptors; the effects of corticosteroid therapy in brain-dead kidney donors, a double-blind, randomized, controlled trial. Molecular Immunology. 2018;

60. E. H, I. H, R. K, S. S, M. L, A. N. The impact of deceased donor simvastatin treatment on kidney transplant outcomesresults of a double-blinded, randomized controlled trial. Transplantation. 2018;

61. Nykanen I A, Holmstrom EJ, Tuuminen R, Krebs R, Dhaygude K, Kankainen M, et al. Donor Simvastatin Treatment in Heart Transplantation A Randomized and Blinded Clinical Trial. CIRCULATION. 2019;

62. Frenette AJ, Williamson D, Williams V, Lagacé AM, Charbonney E, Serri K. A Pilot Randomized Controlled Trial Comparing Levothyroxine to Placebo in Neurologically Deceased Donors. Progress in Transplantation. 2019;

\section{Figures}




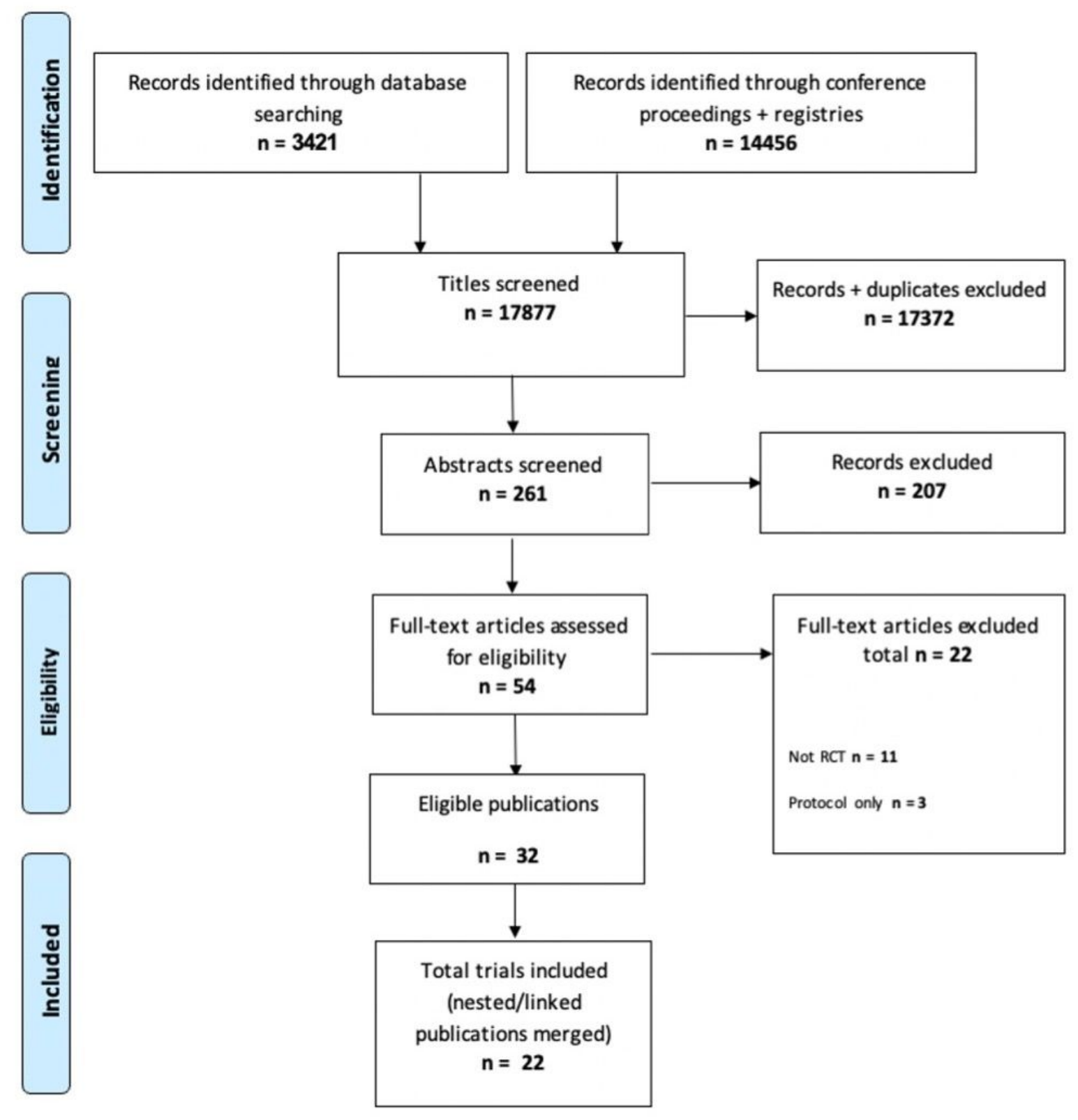

Figure 1

PRISMA Flowchart Legend: Prisma flowchart describing the process of selecting studies for the systematic review 


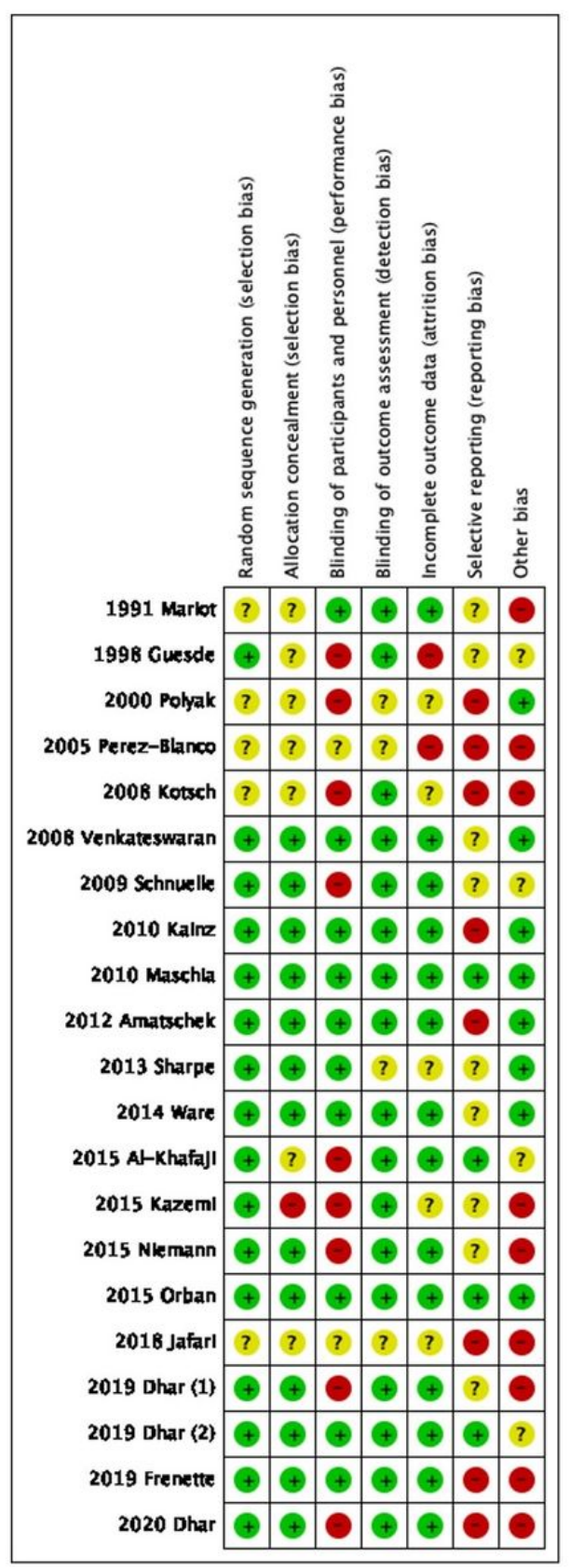

Figure 2

Risk of bias overview Cross tabulation of risk of bias assessments for all 22 included RCTs, by year of publication 


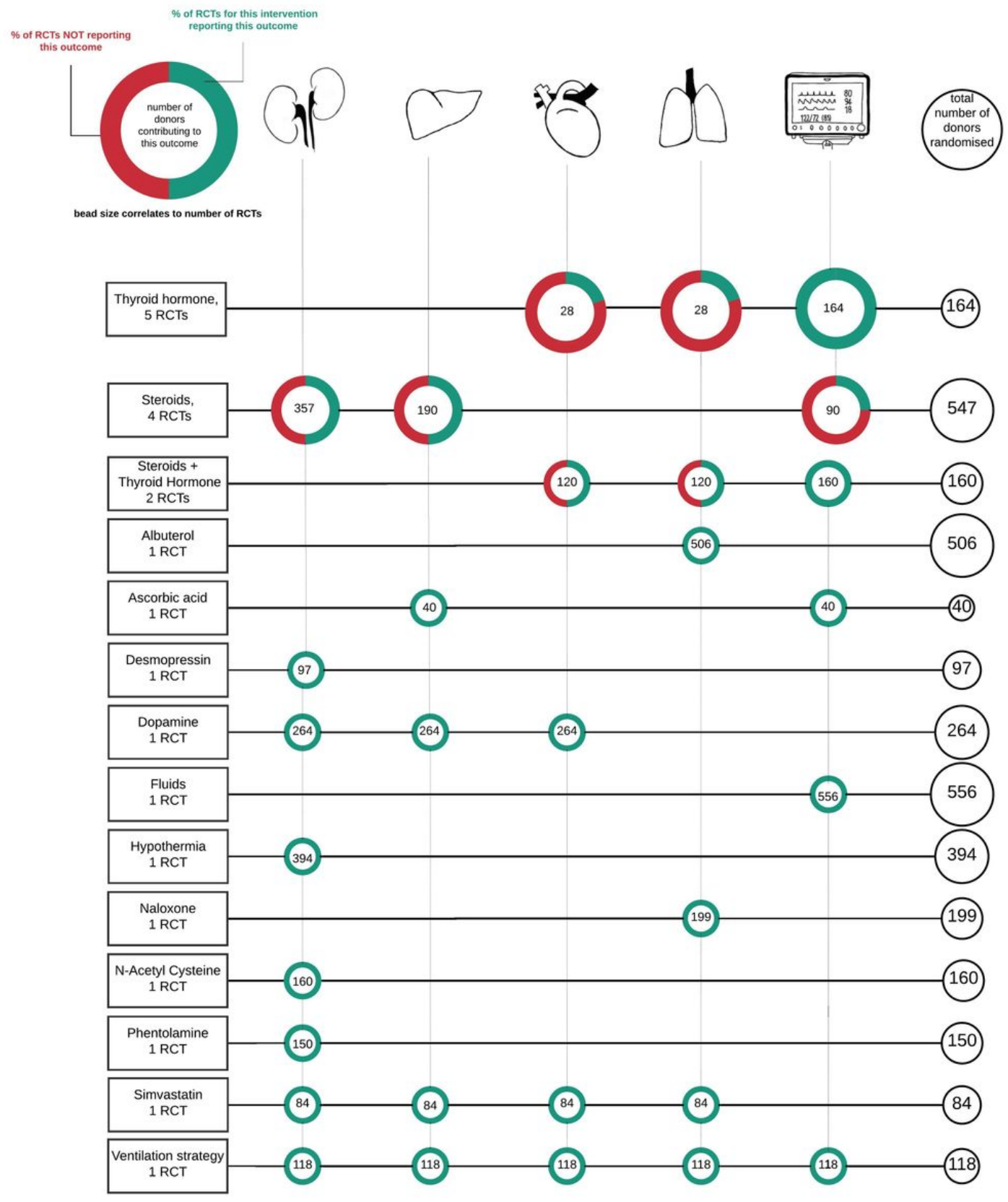

\section{Figure 3}

Outcomes by intervention Legend: Abacus diagram overview of outcomes from donor management trials by intervention. Steroids and/or thyroid hormones were the most commonly studies interventions, with all other interventions only addressed in one trial each (shown alphabetically). For each studied intervention, the overall number of donors randomised is shown on the right-hand side, with a breakdown how many donors contributed to each outcome group shown in vertically aligned beads. Each bead demonstrates how many of the included trials reported this outcome (in green) and how many did not (in red) 
Early, within 30 days

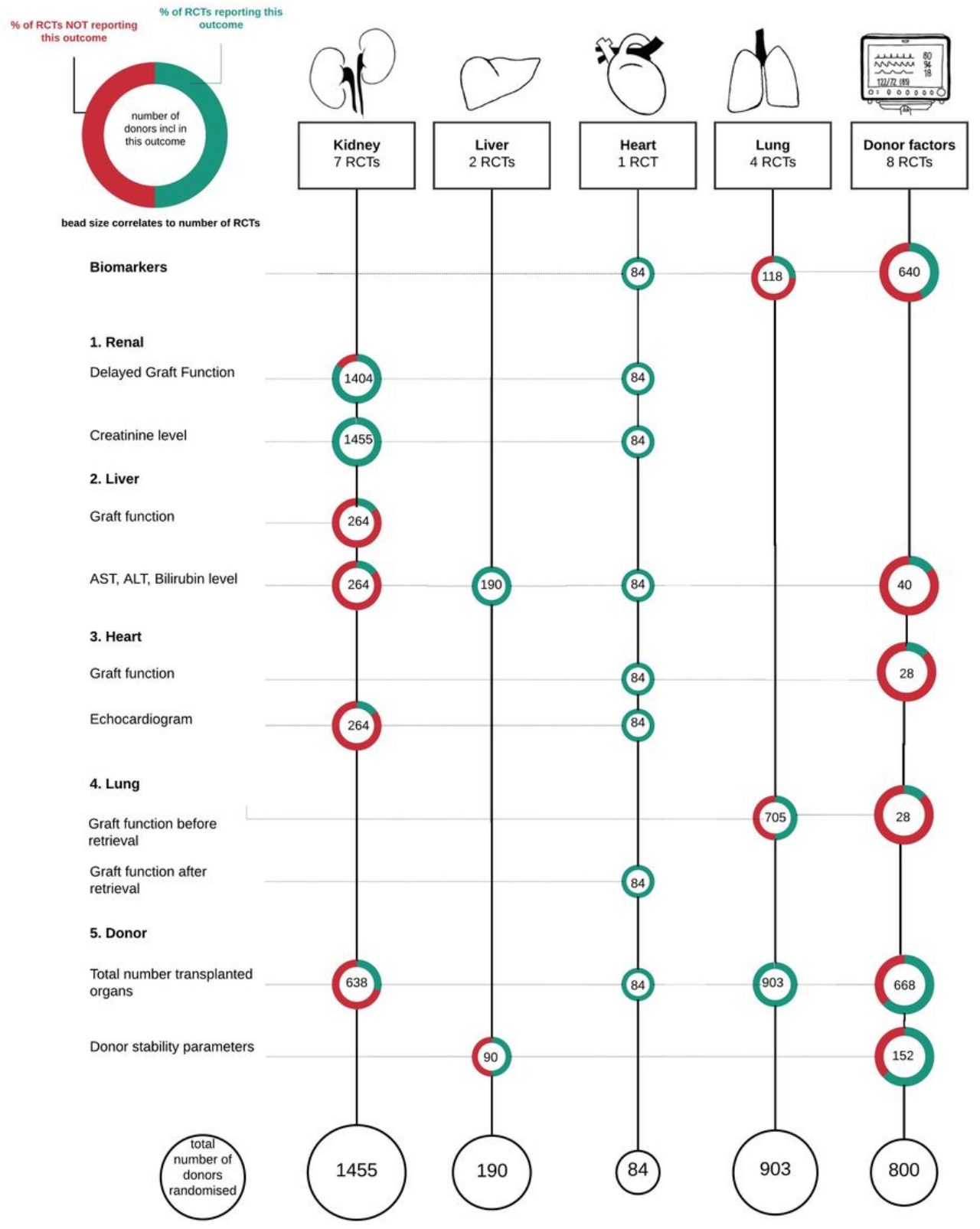

\section{Figure 4}

Early outcomes (<30 days) by target organ Legend: Vertical Abacus diagram summary of reported early outcomes (within 30 days of donor intervention) by primary target. The total number of donors randomised to each primary target group is shown at the bottom, with the kidney as the most commonly studied primary target. Outcomes relating to other organs, donor specific parameters (such as total number of transplanted organs or donor stability) or measured biomarkers are aligned horizontally. Each bead indicates how many of the studies reported each specific outcome (in green) and how many did not (in red) 

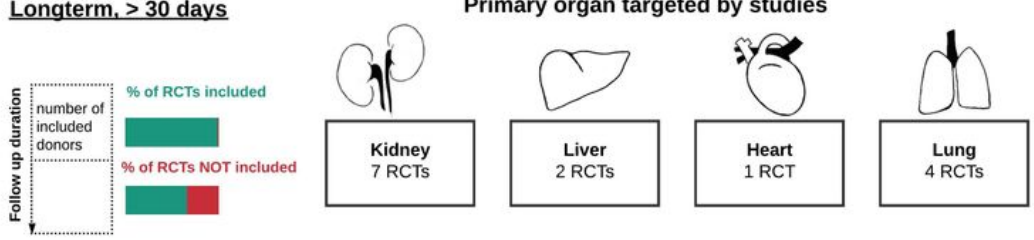

Recipient survival

6 months
1 year
3 years
5 years
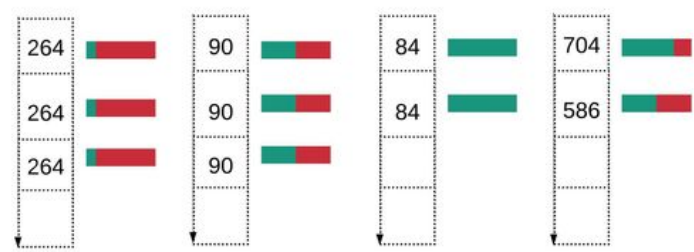

Graft survival
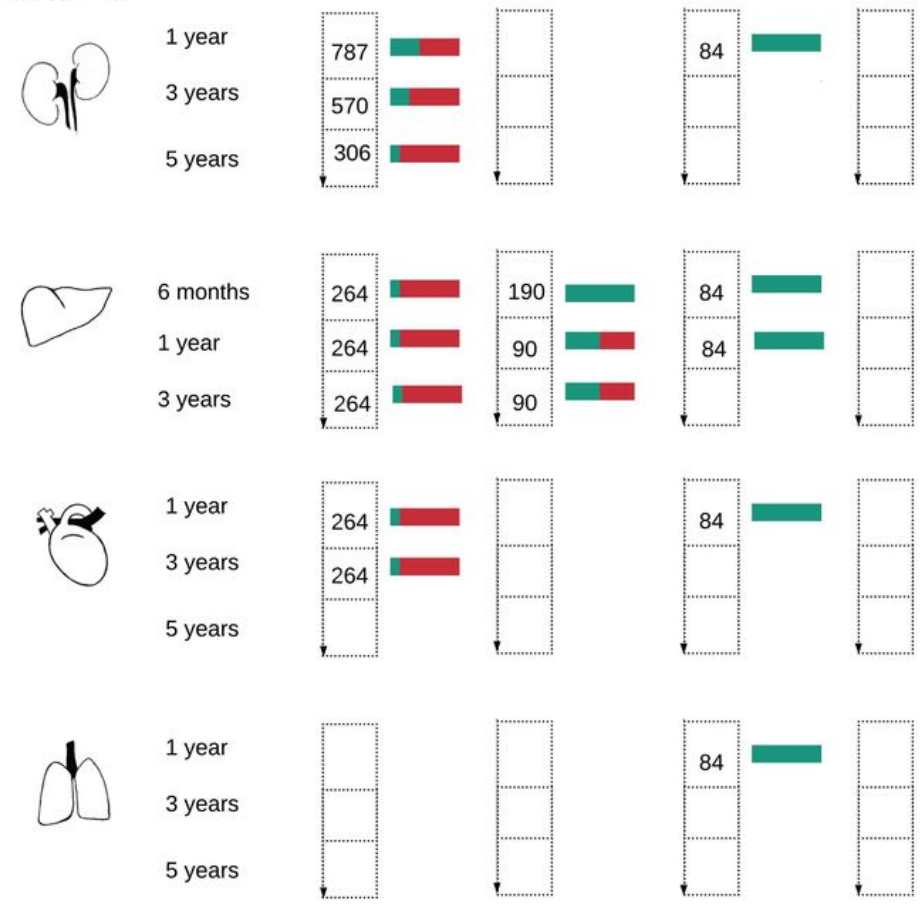

Total number donors randomised

1455

190

84

903

\section{Figure 5}

Duration of graft and recipient survival follow up, by target organ Legend: Summary of long term outcomes assessed in donor management trials, broken down into recipient vs graft survival follow up for each primary targeted donor organ. For each time point, the number of donors followed up to this time point is indicated. A breakdown shows how many studies include this follow up time point and outcome (in green) vs do not report this follow up time point (in red). Trials primarily focused on donor stability did not report long term recipient or graft follow up and are therefore not depicted.

\section{Supplementary Files}

This is a list of supplementary files associated with this preprint. Click to download.

- Additional1SuppIPRISMAchecklist.doc

- Additionalfile2searchstrategy.docx 
- Additionalfile3riskofbiasgraph.jpg

Page 22/22 